\title{
Az Európai Újraélesztési Társaság (ERC) 2021. évi, alapszintü újraélesztésről (BLS) szóló ajánlásának(1) összefoglaló bemutatása
}

\author{
Priskin Gábor, Schiszler Bence, \\ Pécsi Tudományegyetem Egészségtudományi Kar, Sürgősségi Ellátási és Egészségpedagógiai Intézet, \\ Oxyológiai, Sürgősségi Ellátási Tanszék \\ Pandur Attila, Tóth Balázs, \\ Pécsi Tudományegyetem Egészségtudományi Kar, Sürgősségi Ellátási és Egészségpedagógiai Intézet, \\ Oxyológiai, Sürgősségi Ellátási Tanszék, Pécsi Tudományegyetem Egészségtudományi Doktori Iskola \\ Oxyológiai, Sürgősségi Ellátási Tanszék \\ Prof. Dr. Betlehem József, \\ Pécsi Tudományegyetem Egészségtudományi Kar, Sürgősségi Ellátási és Egészségpedagógiai Intézet \\ Dr. Radnai Balázs, \\ Pécsi Tudományegyetem Egészségtudományi Kar, Sürgősségi Ellátási és Egészségpedagógiai Intézet, \\ Oxyológiai, Sürgősségi Ellááási Tanszék
}

\section{Bevezetés}

A World Health Organization (WHO) 2019-es, legújabb, globális halálozási adatai(2) szerint a világon továbbra is vezető halálokként jelölhetők meg az iszkémiás szívbetegségek. Ezen kórfolyamatok gyakran okoznak keringésmegállást, mely hátterében leginkább a szívet ellátó erek károsodása, arteriosclerosisa, atherosclerosisa, vagy zsíros plakkosodása állhat. Ugyancsak kialakulhat arreszt állapot a szívizom iszkémia miatti károsodásból, megvastagodott szívizomzat következményeként, és malignus ritmuszavarokból fakadóan. Az előjelek nélküli, hírtelen bekövetkező szívhalál (SCA) kóroka 80\%-ban koronária betegeségből kialakuló esemény, aminek bizonyítására sokszor csak a pathológiai diagnózis alkalmas(3). A szívmegállás terápiája alapszinten a kardiopulmonális reszuszcitáció (CPR) illetve a félautomata külső defibrillátorral (AED) történő defibrilláció, ugyanis a keringésmegállások nagyjából harmadában kamrafibrilláció (VF) áll fenn(4). Számos kutatás számolt be arról, hogy a laikusok által megkezdett CPR jelentősen képes növelni a betegek túlélési esélyeit(5). Az ERC 2021. évi ajánlása éppen ezért külön fejezetben foglalkozik az alapszintű újraélesztéssel, amely 5 fö üzenetet tart fókuszban:

1. A keringésmegállás felismerésének fontossága

2. Az ellátói lánc megkezdése, a sürgősségi ellátórendszer riasztása

3. A mellkaskompresszió megkezdése
4. ED biztosítása
5. A minőségi CPR elsajátítása

\subsection{A keringésmegállás felismerése}

A keringésmegállás fogalmi meghatározása érdemben nem változott, továbbra is legegyszerübben, mint az eszméletlen, nem reagáló beteg hiányzó vagy abnormális légzésével lehet definiálni. A carotis pulzus hiánya, bár még 2015 előtt szerepelt az ajánlásban ennek felismerési szüksége, továbbra sem elvárt az első ellátóktól, mivel annak megítélése nehéz feladat(6). A keringésmegállás diagnózisának csupán légzéshiányra alapozó felállítása természetesen magában hordozza a felülértékelés, vagyis az álnegativitás lehetőségét, amely kockázat azonban alulmúlja a szükséges CPR elmaradásának kockázatát. A lassú, erőlködő, agonális (gaspoló) légzés is keringésmegállási jelnek tekintendő, az eddigi gyakorlatnak megfelelően. A keringésmegállás felismerése kapcsán megjegyzendő, hogy kezdeti fázisában görcsös mozgások fordulhatnak elö(7). E mozgás megszűnését követően kell a beteg vizsgálatát végrehajtani, amennyiben szükséges, újraélesztést kezdeni.

A beteg iniciális vizsgálata a biztonságos helyszín megállapítása után törtjén, első lépésként kontaktusba vonással, mely a beteg vállának enyhe megrázását és 
szóbeli kérdés feltevését jelenti. Az algoritmust az 1. ábra mutatja be.

Nem reagál, hiányzó vagy abnormális légzés

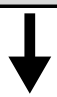

Hívja a mentőszolgálatot!

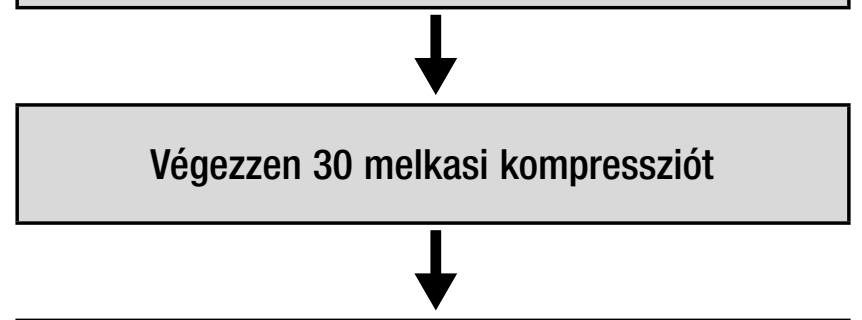

Alkalmazzon 2 befúvásos lélegeztetést

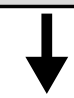

Folytassa az újraélesztést 30:2 aránnyal

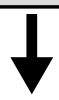

Amint az AED megérkezik, kapcsolja be és kövesse az utasításokat

1. ábra-BLS algoritmus

\subsection{Az ellátói lánc megkezdése, a sürgősségi ellátórendszer riasztása}

Amint az egyszerü kontaktusba vonási kísérletünk alapján azt érzékeljük, hogy a beteg eszméletlen, segítségért kell kiáltani. Ezután a beteg fejét hátrahajtva (HTCL manőverrel) hármas észleléssel vizsgáljuk a légzését maximálisan 10 másodpercig. Amennyiben a betegnek nincs légzése vagy abnormális az, azonnal aktiválni kell az ellátási láncot, mely a 112-es telefonszám hívásával történik. Ha az ellátó egyedül van a helyszínen, a hívást kihangosítással, közben CPR-t kivitelezve hajtsa végre. Ha az ellátónak nincs lehetősége segélyhívásra, elöször a sürgősségi láncot kell megindítania, ha ez a beteg magára hagyását jelenti is.

\subsection{Mellkaskompressziók megkezdése}

A mellkaskompressziók minőségi kivitelezése továbbra is az alap- és emeltszintű újraélesztés fontos eleme, mely számos összetevő megfelelő ismeretét és kivitelezési képességét igényli:

- Minél előbb meg kell kezdeni a kompressziókat

- A mellkas közepén, a szegycsont alsó felén kell kivitelezni (8)

- Legalább 5, de legfeljebb 6 cm mélyre kell nyomni a mellkast (9)

- A lehető legrövidebb megszakításokkal 100-120/ perc-es frekvenciával kell nyomni a mellkast (10)

- A mellkast lenyomás után teljesen fel kell engedni (11)

- Szilárd felületen kell kivitelezni a mellkasi nyomásokat (12)

A kéztartással kapcsolatos ajánlás sem változott, az egyik kézre kulcsolt másik kéz tövével, egyenes karokkal kell nyomni a mellkast úgy, hogy az ellátó az ellátandó mellkasa felett helyezkedik el, az optimális nyomások érdekében. Az ellátó továbbra is a 2015. évi ajánlásban(13) is már megtalálható 30 mellkasnyomás, 2 lélegeztetés szekvenciát kell, hogy kövesse. Amenynyiben ez valamiért nem kivitelezhetö, folyamatos mellkaskompressziót kell végezni.

A lélegeztetés kivitelezése szempontjából, szintén a 2015. évi ajánlás a kiindulási alap, a beteg fejét hátrahajtva, orrát befogva a szájába kell fújni egy normál légvételnyi levegőmennyiséget úgy, hogy közben az ajkainkkal zárjuk az övét. A hatékonyság visszajelzését a mellkas emelkedése szolgálja. A folyamat nem lehet 10 másodpercnél hosszabb.

\subsection{AED alkalmazása}

A félautomata külső defibrillátorokra vonatkozóan sincs változás 2015-ben megjelent ajánláshoz képest, az eszköz helyének egyértelmű jelzése elengedhetetlen, használata pedig minél előbb meg kell, hogy történjen. Ha több ellátó van jelen, folyamatos mellkaskompresszió mellett kerüljenek felhelyezésre az elektródák. Az analízis és esetleges sokkleadás ideje alatt senki ne érjen a beteghez, akár sokkolandó akár nem sokkolandó a ritmus, az eszköz utasítása szerint egyből folytatni kell a mellkaskompressziókat. Ha már fent vannak az elektródák, a sokkleadást ne késleltesse a mellkaskompresszió.

A teljesen automata külső defibrillátorok használata evidencia hiányában nem javasolt. 
A 2015. évi ajánláshoz hasonlóan, a technológia rohamtempójú fejlődése miatt a 2021-ben megjelent ajánlás is külön fejezetet szentel az újraélesztést segítő újító lehetőségeknek, azonban ez a fejezet jóval rövidebb, ajánlást nem tesz, csak összegzi a tudományos környezetét egy-egy potenciális újításnak:

- AED lokalizáló applikáció (14)

- Okostelefonok és okosórák alkalmazása (15)

- Videókommunikáció $(16,17)$

- Mesterséges intelligencia (18-20)

- Drónok alkalmazása (21)

$\mathrm{Az}$ alapszintű újraélesztési ajánlás magában foglalja a légúti idegentest ellátási protokollját is, mely 2015-höz képest nem változott. A legfontosabb a fulladás mielőbbi felismerése (22-24). Amennyiben a beteg eszméletén van, köhögésre kell bíztatni, ha a köhögés nem effektív, váltsunk 5 háti ütésre (elöre döntött és megtámasztott beteg hátának lapockák közötti részére egy kézzel mért ütés). Ha a háti ütéseink sem hatásosak, váltsunk 5 hasi lökésre (25) (kezeket összekulcsolva a köldök és bordakosár közé helyezni és befelé-felfelé mozdítani). Ha továbbra sincs javulás, a háti ütések és hasi lökések ötönként történő cseréje szükséges. Ha a beteg eszméletlenné válik, kezdjünk CPR-t. A szájba nyúlás továbbra is csak akkor javallott, ha biztosan el tudjuk távolítani az idegen testet. Amennyiben hasi lökések kivitelezéséig eljutunk, ha meg is oldódik a fulladás, mindenképp orvosi ellátásra szorul a beteg a szövődmények megelőzése végett.

\section{Az algoritmus (1. ábra) bemutatása lépésről lépésre}

\section{1) BIZTONSÁG}

a. Az ellátó, az ellátandó és a szemlélők biztonságáról való gondoskodás

\section{2) VÁLASZ - válasz keresése}

a. Beteg kontaktusba vonása, vállának gyenge megrázása. Hangos megkérdezése: „Minden rendben?"

\section{3) LÉGÚT - légút átjárhatóságának}

\section{biztosítása}

a. Amennyiben nincs kielégítő válasz a 2) lépésben, a beteg hanyatt fordítása

b. Az ellátó egyik keze a beteg homlokára, másik az állához, a beteg fejének hátrahajtása, áll emelése

\section{4) LÉGZÉS - „Látom, hallom, érzem”}

a. Látni, hallani, érezni a beteg légzését legfeljebb 10 másodpercig

b. Ha a beteg alig légzik vagy ritmustalan, lassú és zajos a légzése, nem légzik normálisan

\section{5) NINCS VAGY ABNORMÁLIS LÉGZÉS - Mentők riasztása}

a. Ha nincs, vagy abnormális a beteg légzése, kérjünk meg valakit, hogy hívjon segítséget, ha erre nincs lehetőség mi magunk hívjunk b. Amennyiben lehet, az ellátó maradjon a beteggel

c. A telefon kihangosítása vagy egyéb kéz nélküli opció alkalmazása, hogy CPR megkezdése mellett lehessen a diszpécserrel beszélni.

\section{6) AED elérhetőségéről való gondoskodás} - Valaki elküldése AED-ért

a. Küldjünk el valakit AED-ért, ha van rá lehetőségünk

b. Ha egyedül vagyunk, ne hagyjuk magára a beteget, kezdjünk CPR-t

\section{7) KERINGÉS - Mellkaskompresszió} kezdése

a. Beteg mellé térdelés

b. Egyik kéz töve a beteg mellkasának közepére (a szegycsont alsó felére)

c. A másik kéz töve az első kéz hátára, ujjak összekulcsolása

d. Egyenes karok

e. A beteg mellkasa felett függőlegesen elhelyezkedni és lenyomni a mellkast legalább $5 \mathrm{~cm}$-re (de nem több, mint $6 \mathrm{~cm}$ )

f. Minden lenyomás után teljes felengedés anélkül, hogy a mellkas és kéz közötti kapcsolat megszünne

g. A lenyomást 100-120/perces frekvenciával ismételni 
8) A LÉLEGEZTETÉS ÉS

MELLKASKOMPRESSZIÓ

KOMBINÁLÁSA

a. Ha képzett az ellátó, 30 mellkaskompresszió után újra nyissa meg a légutat, a HTCL manővert alkalmazva

b. A mutató és hüvelykujj segítségével nyomja össze az orr puha részét

c. Hagyja nyílni a beteg száját, de tartsa fenn az áll emelését

d. Vegyen egy normál mennyiségü levegőt, helyezze ajkait a beteg szájára, meggyőződve a légmentes illeszkedésről

e. Fújjon nyugodtan és folyamatosan a beteg szájába miközben a mellkas emelkedését figyeli nagyjából 1 másodpercig. Ebből következően állapítható meg a hatékony lélegeztetés

f. A HTCL-t fenntartva vegye el a fejét a betegétől és figyelje meg a mellkas süllyedését és a levegö távozását

g. Vegyen egy újabb normál mennyiségű levegőt és ismételten fújjon a beteg szájába

h. A mellkaskompressziót nem szabad 10 másodpercnél hosszabb időre megszakítani a két lélegeztetés miatt akkor sem, ha az egyiket nem sikerült hatásosan kiviteleznünk

i. Ezután késlekedés nélkül folytatódjon a 30 mellkaskompresszió

j. Folytassa a 30:2 mellkaskompresszió: lélegeztetés arányt

\section{9) CSAK KOMPRESSZIÓVAL} KIVITELEZETT CPR

a. Ha az ellátó nem képzett, vagy nem képes a lélegeztetésre, csak mellkaskompressziót folytasson 100-120/perces frekvenciával

10) HA MEGÉRKEZIK AZ AED - AED bekapcsolása és elektródák felhelyezése

a. Amint megérkezik az AED, kapcsoljuk be és helyezzük az elektródákat a beteg csupasz mellkasára

b. Ha több, mint egy ellátó van jelen, az AED felhelyezése közben folyamatos mellkaskompresszióknak kell zajlani

\section{1) A VIZUÁLIS/HALLHATÓ UTASÍTÁSOK KÖVETÉSE}

a. Az AED által adott utasítások követése

b. Ha sokk indokolt, meg kell győződni arról, hogy sem az ellátó, sem senki más nem ér a beteghez

c. A sokk gomb megnyomása

d. A CPR azonnali és folyamatos folytatása, az AED utasításának megfelelően

12) HA SOKK NEM INDOKOLT - CPR folytatása

a. Ha sokk nem indokolt, CPR azonnali és folyamatos folytatása, az AED utasításának megfelelően

13) HA AED NEM ELÉRHETŐ - CPR folytatása

a. Amennyiben AED nem elérhető, VAGY amíg várunk egyre, folytassuk a $\mathrm{CPR}-\mathrm{t}$

b. Az újraélesztést nem szabad abbahagyni amíg:

- Magasabb szintü egység erre utasítást nem ad VAGY

- A beteg egész biztosan magához tér, mozog, nyitja szemét, normálisan lélegzik VAGY

- Az ellátó teljesen ki nem merül

c. Mivel a csupán CPR hatására történő keringésvisszatérés ritka, az abbahagyás csak akkor történjen meg, ha az ellátó biztos benne, hogy a beteg keringése visszatért

d. A keringés visszatérésére utaló jelek:

- Felébredés

- Mozgás

- Szemnyitás

- Normális légzés

14) HA ESZMÉLETLEN, DE NORMÁLISAN LÉGZIK - Stabil oldalfekvő helyzetbe helyezés

15) Ha az ellátó biztos benne, hogy a beteg légzése normális, azonban reakció nem kiváltható, helyezze stabil oldalfekvő helyzetbe

16) Az ellátó álljon készen a CPR újbóli megkezdésének szükségére, ha a beteg légzése leáll vagy abnormálissá válik 


\section{Konklúzió}

Az ERC 2015. évi BLS ajánláshoz képest a fő változást a célirányosság jelenti, minden szempontból az előző ajánlásban közétett információk további hangsúlyozása történt, a legújabb, elmúlt 5 évben megjelent kutatások segítségével. Újból hangsúlyozásra került az egyedül lévő ellátó kéz nélküli segélyhívásának szerepe, illetve az, hogy minden esetben törekedjünk a sürgősségi lánc, beteg magára hagyása nélküli megindítására. A technológiai fejlődés ellenére, bár rendkívül gyors a tempója, az újabb eszközök és

\section{Irodalomjegyzék:}

1. Olasveengen TM, Semeraro F, Ristagno G, et al. European Resuscitation Council Guidelines 2021: Basic Life Support. 2021; Available from: https://doi. org/10.1016/j.resuscitation.2021.02.009

2. Geneva. W. Global Health Estimates 2020: Deaths by Cause, Age, Sex, by Country and by Region, 20002019. Geneva, World Health Organisation. World Health Organization. 2020.

3. Kandala J, Oommen C, Kern KB. Sudden cardiac death. Br Med Bull. 2017 Apr;122(1):5-15.

4. Latest AHA Statistics on Cardiac Arrest Survival Reveal Little Progress. Sudden Cardiac Arrest Foundation. 2021.

5. Yan S, Gan Y, Jiang N, et al. The global survival rate among adult out-of-hospital cardiac arrest patients who received cardiopulmonary resuscitation: a systematic review and meta-analysis. Crit Care. 2020 Apr;24(1):61.

6. Bahr J, Klingler H, Panzer W, et al. Skills of lay people in checking the carotid pulse. Resuscitation. 1997 Apr;35(1):23-6.

7. Clawson J, Olola C, Scott G, et al. Effect of a Medical Priority Dispatch System key question addition in the seizure/convulsion/fitting protocol to improve recognition of ineffective (agonal) breathing. Resuscitation. 2008 Apr;79(2):257-64.

8. Cha KC, Kim HJ, Shin HJ, et al. Hemodynamic Effect of External Chest Compressions at the Lower End of the Sternum in Cardiac Arrest Patients. J Emerg Med. 2013 Apr;44(3):691-7.

9. Sutton RM, Case E, Brown SP, et al. A quantitative analysis of out-of-hospital pediatric and adolescent lehetőségek használatára továbbra sem ajánlás szintű a rendelkezésre álló bizonyíték.

Az elmúlt 5 évben számos kutatás foglalkozott az alapszintű újraélesztés kérdéseivel, azonban a tudomány jelen állása szerint nem történt olyan tudományos felfedezés, mely a 2015-ben kiadott ajánlás módosítását indokolná, így a 2021. évi ajánlás döntően az előző ajánlásban foglaltakat hangsúlyozza.

resuscitation quality - A report from the ROC epistrycardiac arrest. Resuscitation. 2015 Apr;93:150-7.

10. Idris AH, Guffey D, Aufderheide TP, et al. Relationship between chest compression rates and outcomes from cardiac arrest. Circulation. 2012 Jun;125(24):3004-12.

11. Cheskes S, Common MR, Byers AP, et al. The association between chest compression release velocity and outcomes from out-of-hospital cardiac arrest. Resuscitation. 2015 Apr;86:38-43.

12. Holt J, Ward A, Mohamed T-Y, et al. The optimal surface for delivery of CPR: A systematic review and meta-analysis. Resuscitation. 2020 Apr;155:159-64.

13. Greif R, Lockey AS, Conaghan P, et al. European Resuscitation Council Guidelines for Resuscitation 2015. Section 10. Education and implementation of resuscitation. Resuscitation. 2015;95:288-301.

14. Burkart R, Semeraro F, Greif R, et al. European Resuscitation Council Guidelines 2021: Systems saving lives. 2021;1-18. Available from: https://doi. org/10.1016/j.resuscitation.2021.02.008

15. Hostler D, Everson-Stewart S, Rea TD, et al. Effect of real-time feedback during cardiopulmonary resuscitation outside hospital: prospective, clusterrandomised trial. BMJ. 2011 Apr;342:d512.

16. Lee SY, Song KJ, Shin S Do, et al. Comparison of the effects of audio-instructed and video-instructed dispatcher-assisted cardiopulmonary resuscitation on resuscitation outcomes after out-of-hospital cardiac arrest. Resuscitation. 2020 Feb;147:12-20.

17. Kim C, Choi HJ, Moon H, et al. Prehospital advanced cardiac life support by EMT with a smartphone-based 
direct medical control for nursing home cardiac arrest. Am J Emerg Med. 2019 Apr;37(4):585-9.

18. Gulshan V, Peng L, Coram M, et al. Development and validation of a deep learning algorithm for detection of diabetic retinopathy in retinal fundus photographs. JAMA - J Am Med Assoc. 2016 Dec;316(22):2402-10.

19. Rajkomar A, Oren E, Chen K, et al. Scalable and accurate deep learning with electronic health records. Vol. 1, arXiv. arXiv; 2018. p. 18.

20. Blomberg SN, Folke F, Ersbøll AK, et al. Machine learning as a supportive tool to recognize cardiac arrest in emergency calls. Resuscitation. 2019 May;138:322-9.

21. Vögele A, Ströhle M, Paal P, et al. Can drones improve survival rates in mountain areas, providing automated external defibrillators? Resuscitation. 2020 Apr;146:277-8.
22. Igarashi Y, Yokobori S, Yoshino Y, et al. Prehospital removal improves neurological outcomes in elderly patient with foreign body airway obstruction. Am J Emerg Med. 2017 Oct;35(10):1396-9.

23. Kinoshita K, Azuhata T, Kawano D, et al. Relationships between pre-hospital characteristics and outcome in victims of foreign body airway obstruction during meals. Resuscitation. 2015 Mar;88:63-7.

24. Vilke GM, Smith AM, Ray LU, et al. Airway Obstruction in Children Aged Less Than 5 Years: The Prehospital Experience. Prehospital Emerg Care. 2004 Apr;8(2):196-9.

25. The choking controversy: critique of evidence on the Heimlic... : Critical Care Medicine. 